\title{
Climate Change and Its Impact on Sustainable Development in Bangladesh
}

\author{
Md. Ashraful Islam, ", Md. Saiful Islam² \\ ${ }^{1}$ ICT-GIS Division Institute of Water Modelling, Dhaka, Bangladesh \\ ${ }^{2}$ Department of URP, Khulna University of Engineering \& Technology (KUET), Khulna, Bangladesh \\ Email address: \\ Rony.ashraful@gmail.com(Md. A. Islam),plnr.shaiful31@gmail.com (Md. S. Islam) \\ *Corresponding author
}

\section{To cite this article:}

Md. Ashraful Islam, Md. Saiful Islam. Climate Change and Its Impact on Sustainable Development in Bangladesh. International Journal of Economy, Energy and Environment. Vol. 2, No. 6, 2017, pp. 90-95. doi: 10.11648/j.ijeee.20170206.11

Received: September 27, 2017; Accepted: October 25, 2017; Published: November 20, 2017

\begin{abstract}
There has been a large scientific evidences on climate change and its direct as well as indirect influences. Every year around 2.5 million people die from non-infectious diseases, which are directly attributable to environmental factors and these are related to climate changes. So Climate change is one of the most important issues in present senario. Changes in conditions and climate variability affect temperature, sea level rise, poverty, rising salinity, greenhouse effect and it can also affect human health both directly and indirectly. Though Bangladesh is a very low energy consuming country, Bangladesh is one of the top 10 nations that are mostly vulnerable to climate changes. This study was carried out by employing a general review of literature on climate change, focusing on its effects in Bangladesh and sustainable development. The effects would be as Crop production will decrease, floods are contaminating water that Increasing water borne diseases such as cholera, diarrhea etc. If the global temperature rises by $2^{\circ} \mathrm{C}, 30 \%$ of all land species will be threatened by an increased risk of extinction. About $75 \%$ area of mangrove forest Sundarban will submerse if the sea level will increases $45 \mathrm{~cm}$. The southwestern coastal districts of Bangladesh will increase $16 \%$ in 2050 and $18 \%$ in 2100 , which will make people homeless and bring social instability.
\end{abstract}

Keywords: Climate, Effect, Temperature, Vulnerability, Sustainable Development

\section{Introduction}

CLIMATE change is the biggest global threat of the $21 \mathrm{st}$ century and is increasingly recognized as a public health priority [1]. Bangladesh is one of the largest deltas in the world which is highly vulnerable to Natural Disasters because of its Geographical location, Flat and low-lying landscape, Population density, Illiteracy, Poverty, Lack of Institutional setup etc. The objective of this paper is the actual situation and condition about the real impact of climate change and vulnerability to climate change and its negative impacts in public health, environmental resources, such as, water and air quality, temperature increase, poverty, natural disasters and other subjects, especially in Bangladesh. Human induced climate change threatens ecosystems and human health [2]. Climate change will have its greatest and most impact on those poorest in the world and it will deepen inequities and the effects of global warming will shape the future of health among all peoples. During this century, earth's average temperature rises are likely to surpass the safe threshold of $2^{\circ} \mathrm{C}$ above pre-industrial average temperature [3]. Rises will be greater at higher latitudes with medium-risk scenarios predicting 2 to $3^{\circ} \mathrm{C}$ rises by 2090 and 4 to $5^{\circ} \mathrm{C}$ rises in northern Canada, Greenland, and Siberia [4]. The average temperature of today's world has already increased by $0.6^{\circ} \mathrm{C}$ from the middle of the $1800 \mathrm{~s}$. In the last century average temperature of earth has increased by 1.5 to $4.5^{\circ} \mathrm{C}$ leading to melting of polar and mountain ice and thus sea level rise [5]. It has also been shown that if climate change continues extreme in the year 2050, production of rice will decrease by $8 \%$ and that of wheat by $32 \%$ [6]. Over the last 50 years, cold days, cold nights, and frost have become less frequent, while hot days, hot nights, and heat waves have become more frequent. The linear warming trend over the last 50 years of on average $0.13^{\circ} \mathrm{C}$ per decade is nearly twice that for the last 100 year. The total temperature increase from the period 1850 to 1899 to the period 2001 to 2005 has been $0.76^{\circ} \mathrm{C}$ [7]. According to the International Panel for Climate Change 
(2007), an increase in the average global temperature will lead to changes in precipitation and atmospheric moisture due to the changes in atmospheric circulation and increases in evaporation and water vapor. Expected population growth and migration mean that urban expansion will be the most universal development challenge. Rapid urbanization and climate change have given it a new sense of urgency. When urban expansion can take the form of urban sprawl then it is costly, wasteful, and ecologically destructive [2]. By 2050, the urban population of the developing world will be 5.3 billion; Asia will host $63 \%$ of the world's urban population, or 3.3 billion people and The United Nation predicts that here will be millions of environmental migrants by 2020, and climate change is one of the major drivers. Climate change is taking measure not only on the ecology of nations around the world but also their political, economic and social stability with the poorest nations and the poorest of the rich nations being the worst sufferers [8]. A one meter rise in sea level could for instance flood $17 \%$ of Bangladesh's land area and that could threaten large parts of coastal cities such as Lagos, Cape Town, small island Maldives. A World Bank study has estimated that a one-meter sea-level rise would affect 84 developing countries alone. Recent studies have found that up to $12 \%$ of the world GDP is already at risk from existing climate patterns. For example the value of GDP exposed to tropical cyclones alone more than tripled from US\$526 billion in the 1970 s to US\$1.6 trillion in the first decade of the 2000s [9]. Ultimately if climate change is not being solved, then poverty eradication, food security and other major related problem cannot be solved either [10]. Secretary-General of UN, Ban Ki-moon affirmed that climate change was an "unholy brew" that could create perilous security vacuums, and that we must address a clear danger that not only exacerbated the threats but was itself a threat to international peace and security [9].

Climate change is described as an average weather condition of an area characterized by its own internal dynamics and by changing in external factors that affect climate [13]. According to United Nations Framework Convention on Climate Change (UNFCC) climate change as the change resulting from long term direct and indirect activities that induces changes in the compared time which are much more than the natural change [14]. On the other hand the weather is a set of all the phenomena occurring in a given atmosphere at a given time [15].

\section{Natural Disasters Around the World}

The UNHCR report also pointed out that climate change is the most important factor contributing to natural disasters, and that the international community must recognize this fact, and do more to help the suffering humanity. The UNHCR report also pointed out that About 42 million people around the world were forced to flee their homes because of natural disasters. The alarming matter is the number of internally displaced people because of natural disasters almost doubled between 2009 and 2010. According to UNHCR "mega disasters" like the floods in China and Pakistan, and the earthquake in Chile, and Haiti were responsible for the massive increase in the internally displaced people from 17 million in 2009 to about 42 million in 2010. The weather related hazards like floods and storms were most responsible for more than $90 \%$ of the disaster displacements [11].

Thermal expansion of the oceans is contributing to sea-level rise of on average $1.8 \mathrm{~mm}$ a year since the 1960s. Since 1978 satellites show that the extent of summer Arctic sea ice has fallen by $20 \%$ [12]. A developed country like USA, china, japan also realized the effect of climate change.

\section{Bangladesh}

Geographically Bangladesh is located in the tropical region [16]. Natural disaster is a common phenomenon and till today Bangladesh is facing several disasters, and climate change is the main reason for it. Bangladesh lies on a deltaic plain with five major river systems, that's are the Jamuna-Brahmaputra, the Padma-Ganges, the Surma-Meghna, the Padma-Meghna, and the Karnaphuli. Though altitudes up to $105 \mathrm{~m}$ above sea level occur in the northern part of the plain, most elevations are less than $10 \mathrm{~m}$ above sea level; elevations decrease in the coastal south, where the terrain is generally at sea level. These geographical features make Bangladesh vulnerable to natural disasters such as floods, cyclones and the high levels of poverty increase the enormity of the challenges that the country is likely to face from climate change [17].

According to World Risk Index 2011, jointly conducted by United Nations University (UNU), Germany and the Institute of Environment and Human Security said that Bangladesh ranked sixth among countries that are most vulnerable to natural disasters, while second among the Asian countries [18]. Bangladesh is projected to be 0.5 to $0.2^{\circ} \mathrm{C}$ warmer than today by the year 2030 . The 30 years mean summer temperature in Bangladesh is $27.5^{\circ} \mathrm{C}$ and the mean summer temperature is relatively higher during the monsoon than during summer. Winter season is the driest season in Bangladesh and 30 years mean winter rainfall amounts to about $64 \mathrm{~mm}$ with a variability of around $53 \%$. By 2030 the best estimate projection is for monsoon rainfall to increase by 10 to $15 \%$ and winter rainfall by 5 to $10 \%$ [19]. Bangladesh has got a population of around 150 million (2011) with a life expectancy at birth of about 63 years, and an adult literacy rate of $47.5 \%$. The recent Human Development Report ranks Bangladesh number 140 of 177 nations. Bangladesh has an average annual population growth rate of around $2 \%(4.6 \%$ in urban areas), almost $75 \%$ of the population lives in rural areas and a population density of 954.4 (people per sq. $\mathrm{km}$.).

Since 1970, according to a statistics, about 39 million people have been displaced by major natural calamities like flood and cyclone in the country till 2009. Climatologists warn that about 6-8 million more people of Bangladesh could be displaced due to increase in global temperature and sea-level rise by 2050 [20]. More than 259 extreme natural events hit Bangladesh during the period 1991 to 2009 . More than $80 \%$ of 
the deaths occurred in 1991 in Bangladesh. In 1991, a total of 140,000 people died in Bangladesh [21].

\section{Common Effect of Climate Change}

\subsection{Disappearance of Sundarban, and Wildlife}

Bangladesh and India shares sensitive ecological treasures, such as the mangrove forests of Sundarban and hill forests on Bangladesh's north and eastern border. These forests are rich in bio-diversity. They are also the areas, where members of many ethnic minorities live. It is the joint responsibility of India and Bangladesh to preserve these ecological treasures and to protect the rights of the ethnic minorities, who have been traditionally living there. It was mentioned that the mangrove forests of the Sundarbans, wildlife, and forest species may disappear [22].

\subsection{Rising Salinity Threatens Sundarban}

Decreasing flow of water through the rivers from upstream is being destroy the ecosystem of Sundarban. Climatologists from home and abroad observed that alarming decrease in water flow down the rivers caused high salinity in both water and soil of Sundarban causing a massive change in faunal composition of the forest. Sundarban, lies across the outer deltas of the Ganges, Brahmaputra and Meghna rivers is the largest mangrove forest in the world. The number of timber producing big trees Sundari is decreasing at the proportionate rate at the increase of salinity. Not only sundari other timber producing tree is decreasing at the rate of salinity.

\subsection{People Are Vulnerable to Diseases}

Climate change would make people in Bangladesh vulnerable to increased prevalence of diseases such as cholera, dengue, cardiovascular, respiratory diseases, and malnutrition due to food scarcity and reduction in food production [23]. In 2030 the estimated risk of diarrhea will be up to $10 \%$ higher in some regions than if no climate change occurred. Climate change will also lead to poorer nutrition, putting people with perilous immune systems at more risk of dying of HIV.

\subsection{Changes on Sea Level Rise}

In the 21 st century, climate change is expected to increase the risk of more recurrent and severe floods through higher river flows resulting from unpredictable rainfall in the Ganges-Brahmaputra-Meghna system during the monsoon and being increase melting of the Himalayan glaciers. About $53 \%$ of the coastal areas are affected by salinity. As a result, increasing salinity in coastal drinking water with severe health consequences to surrounding populations [6]. Millions of people in northern Bangladesh are threatened by riverbank erosion and severe droughts [24]. Groundwater, crop soils and many rivers are likely to become increasingly saline from higher tidal waves and storm surges as a result of climate change effects [25]. Reduced freshwater flows into the Padma River caused by the Farakka Barrage, climate change induced decreases of dry season rainfall, stronger and more frequent cyclones and sea-level rise and intensified saltwater shrimp farming [8]. Crops would be affected by the consequent salinity and require shifts to alternative land use [26].

\subsection{Changes of Temperature}

The consequences of such a global rise in temperature are many which depend on the extent of temperature rise. Most notably, the mean sea level is expected to rise and local climate is expected to become more severe in nature.

\subsection{Greenhouse Effect}

The increasing of greenhouse gases that threaten to change the climate and from chemicals that reduce the ozone layer. Particulate carbon dioxide and other pollutants from the combustion of fossil fuels, which create the greenhouse. This affect the climate in coming decades. These pollutants also cause of premature death from asthma, heart disease and lung disorders [27]. Though Bangladesh emission low carbon, the people of Bangladesh are more vulnerable by the effect of greenhouse gas. Climatologists predict that if the level of carbon dioxide, methane and so on in the atmosphere continues to rise then the Arctic Ocean free of floating summer ice by the end of the century [28]. According to a survey of Economist Intelligence Unit (EIU) Dhaka has been identified as the second worst city to live for the second consecutive time. The listing was based on 30 factors across five broad categories stability, healthcare, culture and environment, education and infrastructure [11]. According to World Bank report air pollution kills 15,000 Bangladeshis each year [21].

\section{Major Future Projection of Climate Change Impacts in Bangladesh}

\subsection{Crop, Food Production \& Security}

Crop production will decrease $30 \%$ in 2100 and Production of rice \& wheat will reduce $8.8 \%$, and $32 \%$ within 2050 respectively [3]. Rainfall patterns are changed due to climate change crops yields are expected to drop significantly.

\subsection{Health}

More floods are contaminating water that Increasing water borne diseases such as cholera, diarrhea etc. More droughts are decreasing food production. Increasing malnutrition. Injuries, disabilities, psychosocial stress and death are becoming severe for more floods, fires, droughts, heat waves \& cyclones. More greenhouse gases are increasing air pollution and rising respiratory diseases. High salinity in water will affect human health. Rise of temperature will favor for pest and pathogen that will increase dengue, malaria, diarrhea etc.

\subsection{Salinity}

The southwestern coastal districts of Bangladesh at present which will increase $16 \%$ in 2050 and $18 \%$ in 2100 . There are 
$13 \%$ areas are salinity at Bagerhat, Khulna \& Sathkhira in Bangladesh [3].

\subsection{Sea Level Rise}

If the sea level rise, low-lying non-embankment coastal area may be completely inundated. It will increase the risk of coastal salinity. Scarcity of saline free drinking water will increase highly and current agricultural practices will change.

\subsection{Coral Bleaching}

Corals are vulnerable to thermal stress. If the sea surface temperature increases $1-3^{\circ} \mathrm{C}$ then corals bleaching will occur frequently.

\subsection{Biodiversity}

If the global temperature rises by $2{ }^{\circ} \mathrm{C}, 30 \%$ of all land species will be threatened by an increased risk of extinction [3].

\subsection{Mangrove Forest}

If the sea level rise $1 \mathrm{~m}$ then the islands of Bay of Bengal and whole Sundarban will destroy including its fauna \& flora. About $75 \%$ area of mangrove forest Sundarban (60007 Sq. km) will submerse if the sea level will increase $45 \mathrm{~cm}$. [13].

\subsection{Increased Evaporation}

Global average water vapor concentration and precipitation are projected to increase during the 21 st century.

\subsection{Fisheries}

If the water temperature is more than $32^{\circ} \mathrm{C}$ [3], Death rate of shrimp's fingerlings will increase. Diseases of fish may increase. Production of sweet water fish will shrink and extinct if the sea level rise. Carps culture may reduce due to saline water intrusion in the ponds and open water bodies.

\subsection{Climate Refugee or Migration}

In Bangladesh every year, rivers engulf enormous agriculture fields and homesteads, makes the peoples homeless. People who have no way to live in the locality, migrate to urban areas and live in slum with unhygienic conditions.

\section{Sustainable Development and Climate Change}

This migration results into an unbearable pressure on urban utilities such as water and sanitation services. Climate change is believed to affect Bangladesh river system badly as the melting of Himalayan glaciers will result in higher flow of water in the river, which in turn will result into flood and water logging in huge urban areas. The water supply of Dhaka city will face a great crisis as its source of water will not remain sustainable and people will not be able to get sufficient safe drinking water [9].

The cultivation of crops and farming of animals and Aquatic construction of residential buildings which eventually lead humans and animals in migration to urban areas, and beyond, which will bring further pressure on our densely-populated country (a growing number of people will be living in slums ) and accelerate urbanization, which in turn will result in strong competition between urban people for access to social and economic opportunities [29] and increase crime which will lead to a social instability. Overall Linkup Between sustainable development and climate change shown in figure 1 .
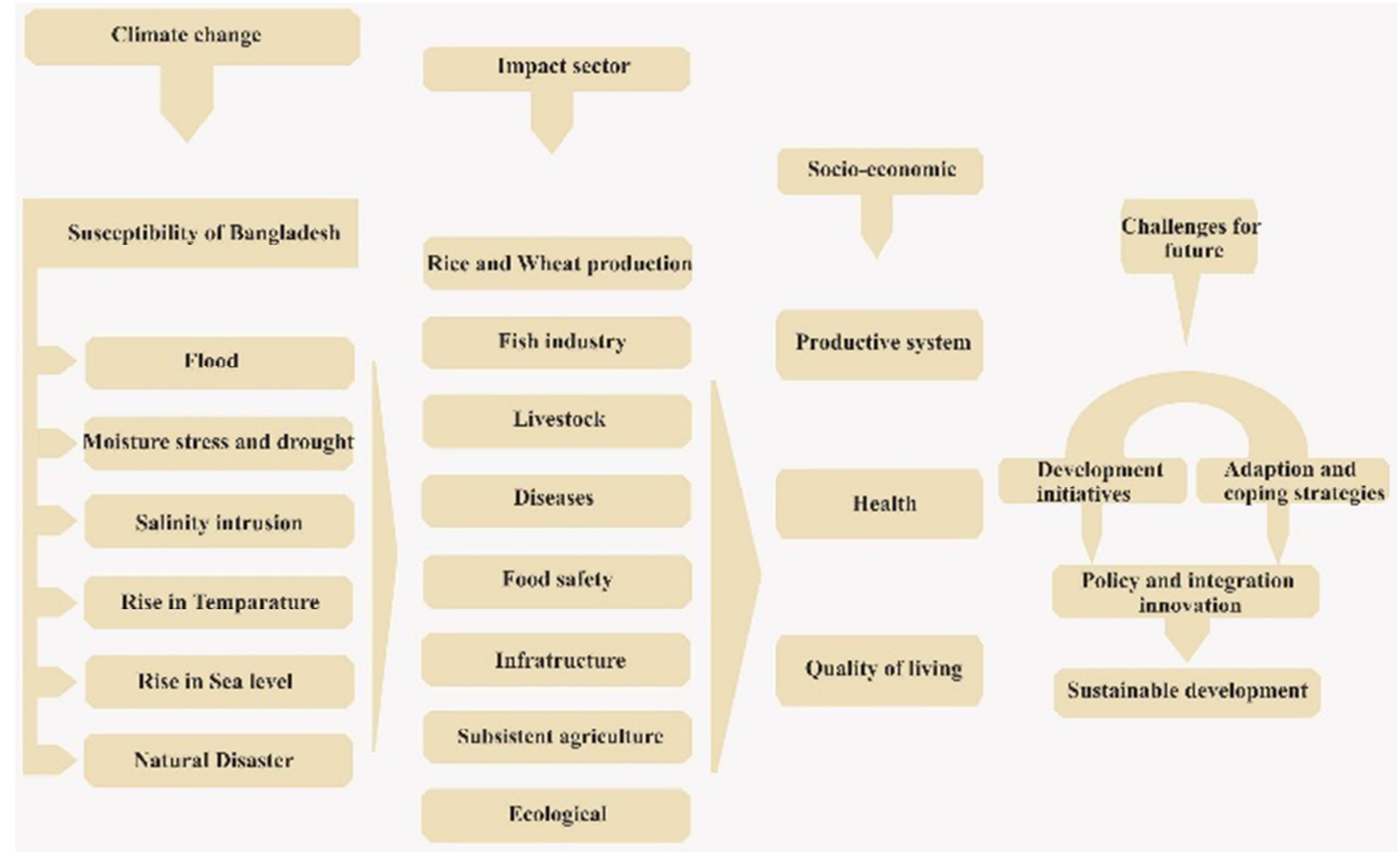

Figure 1. Linkup Between sustainable development and climate change. 


\section{Conclusion}

Climatic change may turn out to be benign or harmful - we do not know. The political commentator, HL Mencken, once said that 'for every problem there is a solution that is simple, direct and wrong'. In the case of climate change the simple, direct and wrong solution is to impose restrictions on emissions of greenhouse gases.

A more constructive perspective suggests that poverty exacerbates all sorts of problems, whether or not they are caused by changes in the earth's climate. Under this view, only by eliminating poverty can we solve the myriad problems that prevent humans from achieving sustainable development. We have a moral responsibility towards fellow human beings who are alive today to ensure that this happens. Let's protect our lovely planet as the safe home for our future generation. Let's not think 'Climate Change' as an individual problem for any country or nation, it's our common issue.

\section{References}

[1] Yongyut Trisurat, Rob Alkemade, and Eric Arets (2009) Projecting forest tree distributions and adaptation to climate change in northern Thailand. JENE. Vol. 1 (3): 055-063.

[2] IIPC (2001). Climate change 2001: the scientific basis. Contribution of Working Group I to the Third Assessment Report of the Inter-governmental Panel on Climate Change (Ed. By J. T. Houghton, Y.).

[3] Anna Tibaijuka (Jan, 2011). Key note address- The Answer Lies in the City. Human Ecology. Jan, 2011.23:1-6. Available at: http://www.thedailystar.net/law/2011/07/04/rights.htm.

[4] AKM Kafiluddin (2005). Human Health, Disease and the Environment. 57/1, Lake Circus, Kalabagan, Dhaka 1205. Accessed on July 13, 2011.

[5] Center for Environmental and Geographic Information Services (CEGIS), Bangladesh.

[6] Climate change and fish culture, Climate Change Cell, Department of Environment \& Forest, Bangladesh.

[7] Costello, Abbas M, Allen A, Ball S, Bell S, Bellamy R, Sharon F, Groce N, Jhonson A, Maria Kett, Lee Maria, Levy C, Maslin M, McCoy David, McGuire B, Montgomery H, Napier D, Pagel, C, Patel J, de Olivira J A Puppim, Redclift N, Rees H, Rogger D, Scott J, Stephenson J, Twigg J, Wolff J, C Patterson (2011) Managing the health effects of climate change. The Lancet. 373: 1693-1733.

[8] Islam, M., Sharif, R. (2015). 'Critical Analysis of Parking Situation of GEC Circle of Chittagong City, Bangladesh'. World Academy of Science, Engineering and Technology, International Science Index 104, International Journal of Civil, Environmental, Structural, Construction and Architectural Engineering, 9 (8), 1122 - 1125.

[9] Daily Star (2011a). Contextually effective steps needed. Web site. (Online). Available: $\mathrm{http}: / /$ www.thedailystar.net/newDesign/news-details.php?nid= 207464. Accessed: Oct, 232014.
[10] S. Ara, M. A. Islam and S. Showkat, "Effect of land-use intensity on surface temperature: A study on Chittagong city corporation area," 2016. 5th International Conference on Informatics, Electronics and Vision (ICIEV), Dhaka, 2016, pp. 72-77. doi: 10.1109/ICIEV.2016.7759971。

[11] Chisty, K., Islam, M., Misuk, S S (2014).:” Analysis of river bank erosion and deposition of Karnafuli River in Chittagong, Bangladesh using remote sensing and GIS approach" 2nd International Conference on Advances in Civil Engineering, 26 -28 Dec, 2014 CUET, Chittagong, Bangladesh.

[12] Khondoker, MSI., Siddiquee, Z., Islam, M, "The Challenges of River Bathymetry Survey Using Space Borne Remote Sensing in Bangladesh", Atmospheric and Oceanic Sciences. Vol. 1, No. 1, 2016, pp. 7-13. doi: 10.11648/j.aos.20160101.12

[13] Islam, M., Siddiquee, Z., Bhadra, S., Chisty, K., "Estimating urban industrial wastewater quantity by using GIS and Radarsat remote sensing data: a case study in Dhaka, Bangladesh", International conference on Water \& Flood Management (ICWFM-2017), Dhaka, Bangladesh.

[14] Islam, M., Siddiquee, Z., Bhadra, S., "Small reservoir monitoring by remote sensing based on Bayesian approach: a study on Dhaka city, Bangladesh", International conference on Water \& Flood Management (ICWFM-2017), Dhaka, Bangladesh.

[15] David Braun (October 20, 2010). "Bangladesh, India Most Threatened by Climate Change, Risk Study Finds". National Geographic. Retrieved 2011-12-21.

[16] FAO (2011). State of forest genetic resources conservation and management in Bangladesh. Available at: http://www.fao.org/docrep/007/ad870e/ad870e01.htm. Accessed on: June 14, 2014.

[17] Global Change (2011). Planet under pressure. Editorial. Vol. 76: 3 .

[18] Kamruzzman, M., Islam, M., Islam, A., Siddiquee, M., "Identification of char lands \& suitability analysis of cropping in dry (winter) season on teesta-jamuna river basin in Bangladesh", Applied Geoinformatics for Society and Environment (AGSE-2017), April 29 - May 04, University of Tehran, Kish Island, Iran.

[19] ICDDR, B (2011a). Our Strategy. Available at: http://www.icddrb.org/what-we-do/publications/cat_view/52publications/10043-icddrb-documents/10055-annual-report/10 056 annual-report-2009/10063-our-strategy-. Accessed on: June 14, 2011.

[20] ICDDR, B (2011b). Centre scientific forum on global population growth. News 'n' Views. June 16, Vol: 5: Issue 12.

[21] IUCH (2010). Climate Change and Child Health Case in Selected Cities of South-western Nigeria. The New York Academy of Medicine, 1216 fifth Ave, NY, 10029. USA.

[22] Mahmood, SAI (2011) Air Pollution Kills 15000 Bangladeshi each year: The role of Public Administration and Government integrity. JPPR, Vol. 3 (4), pp. 129-140, May 2014.

[23] Rahman, M., Siddiquee, M., Islam, M, Muntaheen, A., "Data collection, flood forecasting \& warning message dissemination through smartphone in changing climate", Applied Geoinformatics for Society and Environment (AGSE-2017), April 29 - May 04, University of Tehran, Kish Island, Iran. 
[24] New Age (2011a) Climate change and Poverty. Available at: http://newagebd.com/newspaper1/editorial/23687.html. Accessed on: June 14, 2011.

[25] Sharif, R. Islam, M., "Critical Analysis of Growth Trend \& Growth Pattern of Hill Track: A Study on Khagrachari Hill District, Bangladesh", Landscape Architecture and Regional Planning. Vol. 1, No. 1, 2016, pp. 25-29. doi: 10.11648/j.larp.20160101.14.

[26] Chisty, K., Islam, M., Misuk, S. (2014). 'Determination of Level of Service of Agrabad to CEPZ Road at Chittagong in Bangladesh'. World Academy of Science, Engineering and
Technology, International Science Index 90, International Journal of Social, Behavioral, Educational, Economic, Business and Industrial Engineering, 8 (6), 2021-2024.

[27] Streatfield, K (2008). Population Challenges for Bangladesh in the Coming Decades. J Health Popul Nutr; 26 (3): 261-272.

[28] Islam, M., Chisty, K., Misuk, S (2014).:” E-WASTE recycling practices in Bangladesh (a case study on Chittagong city)" 2nd International Conference on Advances in Civil Engineering, 26 -28 Dec, 2014 CUET, Chittagong, Bangladesh.

[29] Tretwartha TG, Horn HL (1980). An introduction to climate. McGraw Hill, Auckland. 